\title{
Illustrations Part II
}

Frontispiece: Gerard Moerdyk. Voortrekker Monument, Hall of Heroes. 2012 (courtesy of VTM; photo Russell Scott) Figure 01: Hall of Heroes, order of scenes (drawing Tobias Bitterer)

Figure 02: Table explaining standard documentation of scenes (the authors)

Figure 1.1: D. Departure. 1950. Marble, $2.3 \times 7.11 \mathrm{~m}$ (courtesy of VTM; photo Russell Scott)

Figure 1.2: A2. W.H. Coetzer. Reproduction of first sketch for Departure. June 1937 (courtesy of ARCA PV94 1/75/5/1; photo the authors)

Figure 1.3: A3. W.H. Coetzer. 'Uittog uit Kaapland'. After September 1937. Pencil, $13.3 \times 61.2 \mathrm{~cm}$. Revised first sketch (photo courtesy of Museum Africa, no. 66/2194U)

Figure 1.4: A4: W.H. Coetzer. Die uittog van die Voortrekkers uit Kaapland. Late 1937-38? Monochrome oil on board, $26.7 \times 121.9 \mathrm{~cm}$ (courtesy of DNMCH, Art Collection, on loan to VTM Museum; photo Riana Mulder)

Figure 1.5: B2b. Peter Kirchhoff. Departure. 1942-43. Plaster, $77.2 \times 125 \times 8.2 \mathrm{~cm} ; 76.5 \times 125 \times 7.5 \mathrm{~cm}$. Maquettes (courtesy of VTM Museum VTM 2184/1-28; photo Russell Scott)

Figure 1.6: B2a. Peter Kirchhoff. Vendusie. 1942-43. Plaster, $78 \times 89.7 \times 8.2 \mathrm{~cm}$. Rejected maquette with detail of fig. 1.3 on which it was based (courtesy of VTM Museum VTM 2184/1-28; photo Russell Scott)

Figure 1.7: C2a. Departure. 1943. Clay. Full-scale relief (courtesy of HF Archives F 39.10 .7 k, detail of fig. 1.8 photo Alan Yates)

Figure 1.8: Interior of Harmony Hall, Pretoria. Sculptors at work on Departure, 1943 (courtesy of HF Archives F 39.10.7 k; photo Alan Yates)

Figure 1.9: C2b. Departure. 1943. Clay. Revised full-scale clay relief (courtesy of Kirchhoff files; photo Alan Yates)

Figure 1.10a: Routes of treks in the Western Cape. 1835-37 (courtesy of Visagie 2014, foldout opp. p.22)

Figure 1.10b: Routes of treks in the Eastern Cape. 1835-37 (courtesy of Visagie 2014, foldout opp. p.16)

Figure 1.10c: Routes of the main treks. 1835-38 (the authors; drawing Janet Alexander)

Figure 1.11: Voortrekker wagon and detail of linchpin: Afrikaans 'platluns' or 'buspen' (https://upload.wikimedia. org/wikipedia/commons/c/ca/A_aesthetic_linchpin.JPG)

Figure 1.12: Sheep and artefacts, including guitar and accordion, in Departure. Marble, detail of fig. 1.1 (photo Russell Scott)

Figure 1.13: Models for portraits (Potgieter 1987, 11)

Figure 1.14: Photographs and carved portraits of the sculptors in Departure (photos top left to right courtesy of Kirchhoff files; HF Archives F 39.10.8 k, detail; UP Archives, undated Dagbreek Spesiale Monument Uitgawe 1949. Bottom row: photos Russell Scott)

Figure 2.1: D. Presentation. 1949. Marble, $2.3 \times 2.42 \mathrm{~m}$ (courtesy of VTM; photo Russell Scott)

Figure 2.2: A2. W.H. Coetzer. Reproduction of first sketch for Presentation. June 1937 (courtesy of ARCA PV94 $1 / 75 / 5 / 1$; photo the authors)

Figure 2.3: A3. W.H. Coetzer. 'Oorhandiging van Bybel aan Uys'. After September 1937. Pencil, $13.3 \times 15.3 \mathrm{~cm}$. Revised first sketch (photo courtesy of Museum Africa, no. 66/2194F)

Figure 2.4: J. Juta. Settlers presenting a Bible to Jacobus Uys. 1938. Oil on canvas, c. $3.35 \times 9.14$ m. Pretoria City Hall (courtesy of City of Tshwane; photo Helenus Kruger)

Figure 2.5: B2. Hennie Potgieter. Presentation. 1942-43. Plaster, $79 \times 76 \times 10.4 \mathrm{~cm}$. Maquette (courtesy of VTM Museum VTM 2184/1-28; photo Russell Scott)

Figure 2.6: C2. Presentation. 1943-46. Clay. Full-scale relief (courtesy of UCT Thompson A4.123-39; photo Alan Yates)

Figure 2.7: East Cape Treks including the Uys trek beginning in Uitenhage, north-west of Port Elizabeth (courtesy of Visagie 2014, foldout opp. p.16)

Figure 2.8: Models for portraits (Potgieter 1987, 12)

Figure 2.9: Undated Portrait of W.R. Thompson (Newton Thompson 1966, after p.164)

Figure 2.10: Mr Louis van Bergen, model for Jacobus Uys (Van der Walt 1974, 81)

Figure 2.11: 'Thompson' handing Bible to Uys in Presentation. Full-scale clay relief, detail of fig. 2.6 (photo Alan Yates)

Figure 2.12: Ivan Mitford-Barberton. Bible Monument, Grahamstown. 1962. Bronze panels with English settlers presenting Bible (left side of monument) to Voortrekkers (right side) (photos the authors)

Figure 2.13: Uys Bible. 1756. Printed in Dordrecht by Jacob and Hendrick Keur (courtesy of HF VTM Collection B1; photos Russell Scott; the authors)

Figure 3.1: D. Soutpansberg. 1949. Marble, $2.3 \times 2.4 \mathrm{~m}$ (courtesy of VTM; photo Russell Scott)

Figure 3.2: A1. W.H. Coetzer. 'Trichardt Zoutpansberg'. Before June 1937. Pencil, $13.4 \times 15.3 \mathrm{~cm}$. First sketch (photo courtesy of Museum Africa, no.66/2194E)

Figure 3.3: A2: W.H. Coetzer. Reproduction of first sketch for Soutpansberg. June 1937 (courtesy of ARCA PV94 $1 / 75 / 5 / 1$; photo the authors) 
Figure 3.4: A3. W.H. Coetzer. 'Trichardt Zoutpansberg’. After September 1937. Pencil, $13.4 \times 15.3 \mathrm{~cm}$. New sketch (Museum Africa, no. 66/2194A; photo courtesy of Museum Africa)

Figure 3.5: A4. W.H. Coetzer. Trigardt by die Souijtpansberg. Late 1937-38? Oil, $25.4 \times 30.5 \mathrm{~cm}$ (Coetzer 1947, 73)

Figure 3.6: B2a. Hennie Potgieter. Soutpansberg. 1942-43. Plaster, $76.5 \times 89.8 \times 8.5 \mathrm{~cm}$. Rejected maquette (courtesy of VTM Museum VTM 2184/1-28; photo Russell Scott)

Figure 3.7: B2b. Hennie Potgieter. Soutpansberg. 1942-43. Plaster, $78.3 \times 86.6 \times 8 \mathrm{~cm}$. New maquette (courtesy of VTM Museum VTM 2184/1-28; photo Russell Scott)

Figure 3.8: C2. Soutpansberg. 1943-46. Clay. Full-scale relief (courtesy of UP Archives; photo Alan Yates)

Figure 3.9: Models for portraits (Potgieter 1987, 13)

Figure 3.10: Mrs C.F. Ackerman, photographed at the centenary in 1938, model for Trichardt's wife in Soutpansberg. Marble (photos left courtesy of Unisa; right Russell Scott)

Figure 3.11: A.C. Vlok. Kaart by die Dagboek van Louis Trichardt. Coloured map (Trichardt ed. Preller 1938, foldout after last page)

Figure 3.12: Soutpansberg. Background showing schoolhouse, open wagon for trading and Soutpansberg mountains. Full-scale clay relief, detail of fig. 3.8 (photo Alan Yates)

Figure 4.1: D. Delagoa Bay. 1950. Marble, $2.3 \times 2.88$ m (courtesy of VTM; photo Russell Scott)

Figure 4.2: A2. W.H. Coetzer. Reproduction of first sketch for Delagoa Bay. June 1937 (courtesy of ARCA PV94 $1 / 75 / 5 / 1$; photo the authors)

Figure 4.3: B2a. Hennie Potgieter. Delagoa Bay. 1942-43. Plaster, $77 \times 76.5 \times 8 \mathrm{~cm}$. Rejected maquette (courtesy of VTM Museum VTM 2184/1-28; photo Russell Scott)

Figure 4.4: B2b. Hennie Potgieter. Delagoa Bay. 1942-43. Plaster, $76 \times 76.6 \times 8 \mathrm{~cm}$. New maquette (courtesy of VTM Museum VTM 2184/1-28; photo Russell Scott)

Figure 4.5: C2. Delagoa Bay. 1943-46. Clay. Full-scale relief (courtesy of Kirchhoff files; photo Alan Yates)

Figure 4.6: Portrait of Louis Trichardt in Delagoa Bay. Full-scale clay relief (left) and marble (right), details of figs 4.5, 4.1 (photos Alan Yates; Russell Scott)

Figure 4.7: Claude Fuller. Pre 1927. Watercolour (Fuller, Trichardt's Trek 1932, foldout opp. title page)

Figure 4.8: Claude Fuller. Pre 1927. Watercolour. Five maps showing different stages of Trichardt's trek from Soutpansberg to Delagoa Bay (Fuller, Trichardt's Trek 1932, foldouts opp. pp.40, 56, 72, 128, 160)

Figure 4.9: Portuguese-Boer relations in Delagoa Bay - Trichardt handing gun to Gamitto; Gamitto's wife supporting stricken Martha Trichardt. Marble, details of fig. 4.1 (photos Russell Scott)

Figure 4.10: Models for portraits (Potgieter 1987, 16)

Figure 4.11: Portrait of school inspector Jack Pauw as Pfeffer in Delagoa Bay. Marble, detail of fig. 4.1 (photo Russell Scott)

Figure 5.1: D. Vegkop. 1950. Marble, $2.3 \times 4.56$ m (courtesy of VTM; photo Russell Scott)

Figure 5.2: A2. W.H. Coetzer. Reproduction of first sketch for Vegkop. June 1937 (courtesy of ARCA PV94 1/75/5/1; photo the authors)

Figure 5.3: A3. W.H. Coetzer. 'Vegtkop'. September 1937. Pencil, $13.2 \times 22.9 \mathrm{~cm}$. Annotated first sketch (photo courtesy of Museum Africa, no. 66/2194P)

Figure 5.4: W.H. Coetzer. Vegkop - 16 Oktober 1836. 16 October 1936. Pencil drawing, $25.4 \times 38.1 \mathrm{~cm}$ (Coetzer 1947, 106)

Figure 5.5: Heinrich Egersdörfer. Zulus attacking a Boer Laager. c. 1896 (Museum Africa; Muller 1978, 11)

Figure 5.6: B2. Hennie Potgieter. Vegkop. 1942-43. Plaster, $77 \times 123.2 \times 8 \mathrm{~cm}$. Maquette (courtesy of VTM Museum VTM 2184/1-28; photo Russell Scott)

Figure 5.7: C2. Vegkop. 1943-46. Clay. Full-scale relief (courtesy of Kirchhoff files above; courtesy of Romanelli files below, with pencil lines and measurements added for copy process; photo Alan Yates)

Figure 5.8: The Trekkers' Republic 1840-44, showing Vegkop (Walker 1934, foldout opp. p.226)

Figure 5.9: Charles Bell. Interior of Nel's camp during attack. 2 June 1846. Pen and wash, $17.5 \times 24 \mathrm{~cm}$ (Bell Heritage Trust collection; Brooke Simons 1998, 82)

Figure 5.10: Large framing figures in Vegkop, posed for by great-grandchildren of Hendrik Potgieter, Carl Potgieter and Ella Stofberg, his sister. Marble, details of fig. 5.1 (photo Russell Scott)

Figure 5.11: Mrs J.H.M. (Ella) Stofberg, model for framing woman in figure 5.10 (Van der Walt 1974, 80)

Figure 5.12: Models for portraits (Potgieter 1987, 16)

Figure 5.13: Young Paul Kruger in Vegkop (marble, detail of fig. 5.1), posed for by his great-grandson Louis Jacobs, pictured on right (photos Russell Scott; Van der Walt 1974, 80)

Figure 5.14: Coert Steynberg. Colossal bronze statue of a trekker. Vegkop Monument, inaugurated 10 October 1984 (photo courtesy of www.boerenbrit.com/dsc07011)

Figure 5.15a (1-6): Isa Steynberg. The reliefs of Vegkop Monument. Bronze, each $90 \times 139 \mathrm{~cm}$. Inaugurated 1984 (courtesy of Vegkop Monument; photos André Pretorius Photography)

Figure 5.15b: Isa Steynberg. Four drawings (UP Archives, Postma Folder 12; photos the authors)

Figure 6.1: D. Inauguration. 1949. Marble, $2.3 \times 2.82 \mathrm{~m}$ (courtesy of VTM; photo Russell Scott) 
Figure 6.2: A2. W.H. Coetzer. Reproduction of the first sketch for Inauguration. June 1937 (courtesy of ARCA PV94 $1 / 75 / 5 / 1$; photo the authors)

Figure 6.3: A3. W.H. Coetzer. 'Insweering van Retief Winburg'. After September 1937. Pencil, $13.4 \times 15.2 \mathrm{~cm}$. Revised first sketch (photo courtesy of Museum Africa, no. 66/2194B)

Figure 6.4: W.H. Coetzer. 'Retief sworn in as governor of the Voortrekkers' (Nathan 1937, fig. opp. p.164)

Figure 6.5: B2. Hennie Potgieter. Inauguration. 1942-43. Plaster, $77 \times 76 \times 8.5 \mathrm{~cm}$. Maquette (courtesy of VTM Museum VTM 2184/1-28; photo Russell Scott)

Figure 6.6: C2. Inauguration. 1943-46. Clay. Full-scale relief, the right half developed before 1945, the left half later (courtesy of Romanelli files; photo Alan Yates, stitched)

Figure 6.7: Models for portraits (Potgieter 1987, 17)

Figure 6.8: Mother and child in Inauguration. Plaster maquette, full-scale clay relief and marble, details of figs 6.5, 6.6, 6.1 (photos left to right Russell Scott, Alan Yates, Russell Scott)

Figure 6.9: Portraits of Erasmus Smit. Left to right: a photograph taken before 1863 (courtesy of uMsunduzi Museum), and details of plaster maquette and marble in Inauguration, figs 6.5, 6.1 (photos Russell Scott).

Figure 6.10: From Thaba Nchu to Hartplaas. Sites of the two inaugurations of Retief as Voortrekker governor (courtesy of Visagie 2014, foldout opp. p.64)

Figure 6.11: Central group with Retief being sworn in by Gerrit Maritz in Inauguration. Marble, detail of fig. 6.1 (photo Russell Scott)

Figure 6.12: Mother and baby seated behind Retief in Inauguration. Marble, detail of fig. 6.1 (photo Russell Scott)

Figure 6.13: J.H. Amshewitz. Voorwaarts (Onward). 1937. Oil, $3.5 \times 3$ m. Pretoria City Hall (courtesy of City of Tshwane; photo Helenus Kruger)

Figure 6.14: Jan Juta. Mother and child in Settlers presenting a Bible to Jacobus Uys. 1938. Oil on canvas, detail of fig. 2.4. Pretoria City Hall (courtesy of City of Tshwane; photo Helenus Kruger)

Figure 6.15: Jan Juta. The development of the Transvaal, with central group of mother and child. 1938. Oil on canvas, c. $3.35 \times 9.14 \mathrm{~m}$. Pretoria City Hall (courtesy of City of Tshwane; photo Helenus Kruger)

Figure 7.1: D. Kapain. 1949. Marble, $2.3 \times 4.32 \mathrm{~m}$ (courtesy of VTM; photo Russell Scott)

Figure 7.2: B2. Hennie Potgieter. Kapain. 1942-43. Plaster, $77 \times 152.7 \times 9 \mathrm{~cm}$. Maquette (courtesy of VTM Museum VTM 2184/1-28; photo Russell Scott)

Figure 7.3: C2. Kapain. 1943-45. Clay. Full-scale relief (courtesy of Romanelli files; photo Alan Yates, with pencil lines added for copy process)

Figure 7.4: Routes of the main treks with Kapain in the north. 1835-38 (the authors; drawing Janet Alexander)

Figure 7.5: Charles Bell. Koranna Pack-oxen. Watercolour. Undated, $11 \times 17.5 \mathrm{~cm}$ (Collection Dr Frank Bradlow; Brooke Simons 1998, 60)

Figure 7.6: Models for portraits (Potgieter 1987, 18)

Figure 7.7: Hendrik Potgieter on horseback killing Ndebele in Kapain. Marble, detail of fig. 7.1 (photo Russell Scott)

Figure 7.8: Roman sarcophagus with Amazonomachy, Rome. c. AD 140-150. Marble, $65 \times 247 \mathrm{~cm}$ (photo courtesy of the Musei Capitolini 726)

Figure 7.9: Roman battle sarcophagus 'Ammendola', Rome. c. AD 160-180. Marble, $78 \times 211 \mathrm{~cm}$ (courtesy of the Musei Capitolini S 213; photo www.arachne.uni-koeln.de, Mal1683-01)

Figure 7.10: Dying Ndebele and oxen in Kapain. Marble, detail of fig. 7.1 (photo Russell Scott)

Figure 8.1: D. Negotiation. 1949. Marble, $2.3 \times 2.73$ m (courtesy of VTM; photo Russell Scott)

Figure 8.2: A2. W.H. Coetzer. Reproduction of first sketch for Negotiation. June 1937 (courtesy of ARCA PV94 $1 / 75 / 5 / 1$; photo the authors)

Figure 8.3: A3. W.H. Coetzer. 'Onderhandeling met Morokko'. After September 1937. Pencil, $13.4 \times 15.4$ cm. Revised first sketch (photo courtesy of Museum Africa, no. 66/2194C)

Figure 8.4: B2. Frikkie Kruger. Negotiation. 1942-43. Plaster, $77 \times 77 \times 8.5 \mathrm{~cm}$. Maquette (courtesy of VTM Museum VTM 2184/1-28; photo Russell Scott)

Figure 8.5: C2. Negotiation. 1943-45. Clay. Full-scale relief (courtesy of Romanelli files; photo Alan Yates, with pencil lines added for copy process)

Figure 8.6: Area of Thaba Nchu/Blesberg (Landau 2010, 111)

Figure 8.7: 'Wesleyan Miss. Station amongst Barolongs at Thaba Nchu 1839', Black Mountain as backdrop. View from north-west. Drawing (Backhouse 1844, opp. p.411)

Figure 8.8: Isa Steynberg. Hulp van Barolong (Help from the Rolong). Before 1984. Bronze relief, $90 \times 139 \mathrm{~cm}$ (courtesy of Vegkop Monument; photo André Pretorius Photography)

Figure 8.9: Potgieter negotiating with Rolong chief Moroka in Negotiation. Marble, detail of fig. 8.1 (photo Russell Scott)

Figure 8.10: Moerdyk's dog Leeu in Negotiation. Plaster maquette and marble, details of figs 8.4, 8.1 (photos Russell Scott)

Figure 8.11: Models for portraits (Potgieter 1987, 19) 
Figure 9.1: D. Blydevooruitsig. 1949. Marble, $2.3 \times 2.4 \mathrm{~m}$ (courtesy of VTM; photo Russell Scott)

Figure 9.2: A2. W.H. Coetzer. Reproduction of first sketch for Blydevooruitsig. June 1937 (courtesy of ARCA PV94 $1 / 75 / 5 / 1$; photo the authors)

Figure 9.3: A3. W.H. Coetzer. 'Blyde Vooruitsig'. After September 1937. Pencil, $13.5 \times 15.3 \mathrm{~cm}$. Revised first sketch (photo courtesy of Museum Africa, no. 66/2194K)

Figure 9.4: B2a. Hennie Potgieter. Blydevooruitsig. 1942-43. Plaster, $77 \times 89.7 \times 10.3 \mathrm{~cm}$. Rejected maquette (courtesy of VTM Museum VTM 2184/1-28; photo Russell Scott)

Figure 9.5 B2b. Hennie Potgieter. Blydevooruitsig. 1942-43. Plaster, $76 \times 92.2 \times 8 \mathrm{~cm}$. New maquette (courtesy of VTM Museum VTM 2184/1-28; photo Russell Scott)

Figure 9.6: C2. Blydevooruitsig. 1943-46. Clay. Full-scale relief (Potgieter 1987, 20; photo Alan Yates)

Figure 9.7: Models for portraits (Potgieter 1987, 20)

Figure 9.8: Routes, mountain passes and laagers of Voortrekkers in the Drakensberg and Zulu Natal. Late 1837 and early 1838 (courtesy of Visagie 2014, foldout opp. p.98)

Figure 9.9: Black 'breier' in Blydevooruitsig. Marble, detail of fig. 9.1 (photo Russell Scott)

Figure 9.10: Thomas Baines. Detail of African 'breier' in Bloemfontein. 1851. Oil, $38.5 \times 61 \mathrm{~cm}$ (William Fehr Collection; Carruthers and Arnold 1995, 143 fig. 20)

Figure 10.1: D. Debora Retief. 1949. Marble, $2.3 \times 2.39$ m (courtesy of VTM; photo Russell Scott)

Figure 10.2: B2. Laurika Postma. Debora Retief. 1942-43. Plaster, $77 \times 89 \times 8 \mathrm{~cm}$. Left, maquette photographed in storeroom in 2012; right, in raking light as installed in 2017 exhibition (courtesy of VTM Museum VTM 2184/1-28; photos Russell Scott; the authors)

Figure 10.3: C2. Debora Retief. 1943-46. Clay. Full-scale relief (photo Alan Yates; Potgieter 1987, 21)

Figure 10.4: Models for portraits (Potgieter 1987, 21)

Figure 10.5: Models for younger children in Debora Retief. Stephanie and Stephan Joubert, Leah Botha (Van der Walt 1974, 80-82)

Figure 10.6: Topographic Sheets of South Africa (1:50 000). December 2006. Detail, showing Kerkenberg with Retief Rots, upper right, and trek route over Oliviershoek Pass into Natal (roughly following today's R74 on left of map). 2002 (map 2829CA)

Figure 10.7: Entrance to rock formation of Retief Rots with Kerkenberg massif as backdrop (photo courtesy of alamy. com MF8BG7)

Figure 10.8: 'Retiefklip'. Restored Debora Retief inscription in glazed case (photo courtesy of www.boerenbrit.com/ archives/1708/dsc07913\#main)

Figure 10.9: Preparing for adult roles in Debora Retief - girl with doll and boy with kakebeenwa. Marble, detail of 10.1 (photo Russell Scott)

Figure 10.10: Kakebeenwa in front of wagon of the Voortrekker Monument laager (photo courtesy of HF Archives F 40.1.10 k)

Figure 11.1: D. Descent. 1949. Marble, $2.3 \times 4.76 \mathrm{~m}$ (courtesy of VTM; photo Russell Scott)

Figure 11.2: A2. W.H. Coetzer. Reproduction of the first sketch for Descent. June 1937 (courtesy of ARCA PV94 $1 / 75 / 5 / 1$; photo the authors)

Figure 11.3: A3: W.H. Coetzer. 'Drakensberge af'. After September 1937. Pencil, $13.5 \times 30.5$ cm. Revised first sketch (photo courtesy of Museum Africa, no. 66/2194N)

Figure 11.4: B2. Frikkie Kruger. Descent. 1942-43. Plaster, $78 \times 165 \times 9.5 \mathrm{~cm}$. Maquette (courtesy of VTM Museum VTM 2184/1-28; photo Russell Scott)

Figure 11.5: C2. Descent. 1943-45. Clay. Full-scale relief (Potgieter 1987, 22; photo Alan Yates)

Figure 11.6: Models for portraits (Potgieter 1987, 22-23)

Figure 11.7: Model for left Boer in Descent (photo courtesy of Kirchhoff files)

Figure 11.8: Hendrik Ploeger applying clay to full-scale wooden armature for Descent. 1943-45 (courtesy of Kirchhoff files; photo Alan Yates)

Figure 11.9: C1. Hendrik Ploeger. Wooden armature for full-scale clay relief of Descent. 1943-45 (courtesy of Kirchhoff files; photo Alan Yates)

Figure 11.10: Routes, mountain passes and laagers of Voortrekkers in the Drakensberg and Zulu Natal. Late 1837 and early 1838 (courtesy of Visagie 2014, foldout opp. p.98)

Figure 11.11: W.H. Coetzer. Voortrekkers bo-op die Drakensberg (Voortrekkers atop the Drakensberg). Undated. Oil, c. $120 \times 180 \mathrm{~cm}$ (courtesy of DNMCH DHK 5533; photo Helenus Kruger, City of Tshwane)

Figure 12.1: D. Treaty. 1949. Marble, $2.3 \times 2.14 \mathrm{~m}$ (courtesy of VTM; photo Russell Scott)

Figure 12.2: Portrait of Dingane in Treaty. Marble, detail of fig. 12.1 (photo Russell Scott)

Figure 12.3: A1a. W.H. Coetzer. April-June 1937. Pencil, $13.4 \times 15.4 \mathrm{~cm}$. Mirror version of A1b/A3 (photo courtesy of Museum Africa, no. 66/21941)

Figure 12.4: A2. W.H. Coetzer. Reproduction of the first sketch for Treaty. June 1937 (courtesy of ARCA PV94 1/75/5/1; photo the authors) 
Figure 12.5: A3. W.H. Coetzer. 'Traktaat met Dingaan'. After September 1937. Pencil, $13.4 \times 15.3 \mathrm{~cm}$. Revised version of A1b (photo courtesy of Museum Africa, no. 66/2194J)

Figure 12.6: A4. W.H. Coetzer. Die Dingaan-Retief traktaat. Late 1937-38? Monochrome oil on board, $27.3 \times 31 \mathrm{~cm}$ (courtesy of DNMCH, OHG 897; photo the authors)

Figure 12.7: B1a. Frikkie Kruger working on Treaty. 1942-43. Clay maquette (courtesy of VTM Museum; photo the authors)

Figure 12.8: B2. Frikkie Kruger. Treaty. 1942-43. Plaster, 77.5 ×76.7 × $8.5 \mathrm{~cm}$. Maquette (courtesy of VTM Museum VTM 2184/1-28)

Figure 12.9: C1. Hendrik Ploeger. Treaty. 1943-45. Wood, full-scale armature for C2 (courtesy of Kirchhoff files; photo Alan Yates)

Figure 12.10: C2. Treaty. 1943-45. Clay. Full-scale relief (Potgieter 1987, 23; photo Alan Yates)

Figure 12.11: Retief's itinerary, Thaba Nchu/Blesberg, Port Natal and uMgungundlovu. April 1837 to 6 February 1838 (Gledhill and Gledhill 1980, 152)

Figure 12.12: Rev. Daniel Lindley. English translation of Retief's Dutch letter to Dingane. 8 or 18.11.1837 (NARSSA S.S. 1829-1840 1A/R14/37; photo courtesy of Zabeth Botha)

Figure 12.13: James Walton. 'Sketch plan of Dingane's Kraal', showing kwaMatiwane and Owen's camp, not to scale (Oberholster and Walton 1963, centre double page)

Figure 12.14: Synopsis of treaty copies. 1839-91 (table the authors)

Figure 12.15a-b: Cape Volksraad copy of Retief-Dingane treaty text and Pretorius, Landman and Parker certifications. 22.12.1838-9.1.1839. Model for Kew Volksraad copy, fig. 12.16a-c (courtesy of NARSSA Cape Town GH 28/14 pp.508-509; photos Matthew Snyman)

Figure 12.16a-b: Kew Volksraad copy of Retief-Dingane treaty text and Pretorius and Landman certifications. 22.12.1838-9.1.1839. Copy of Cape Volksraad copy (courtesy of NA Kew CO48/200/v2 pp.100-100r; photos the authors)

Figure 12.16c: Kew Volksraad copy of Retief-Dingane treaty and Edward Parker certification. 22.12.1838-9.1.1839. Copy of Cape Volksraad copy (courtesy of NA Kew C048/200/v2 p.101; photo the authors)

Figure 12.17: De Zuid-Afrikaan copy of Retief-Dingane treaty. 22.12.1838-9.1.1839 (De Zuid-Afrikaan, 16.2.1839)

Figure 12.18: Den Haag Copy of Retief-Dingane treaty. 1839-42 (Muller 1978, 59 fig. 30)

Figure 12.19: Fiji Copy of Retief-Dingane treaty. 16.5.1891 (courtesy of NARSSA; photo Gerrit Wagener)

Figure 12.20a: Weinthal facsimile of Retief-Dingane treaty. 16.5.1891 (Leyds 1906, foldout opp. p.46)

Figure 12.20b: Potgieter certification on the Weinthal facsimile of Retief-Dingane treaty. 16.5.1891 (Leyds 1906, foldout opp. p.46)

Figure 12.21: Pretoria copy of Retief-Dingane treaty, perhaps model for Weinthal facsimile. Possibly 1838-39. Woven foolscap (courtesy of NARSSA, Gerrit Wagener; photo the authors)

Figure 12.22: Two opponents facing each other in Treaty - Dingane signs the land cession to which Retief points. Marble, detail of fig. 12.1 (photo Russell Scott)

Figure 12.23: The parties of opponents in Treaty - heads of Zulu and Boers, Thomas Halstead among the latter without hat. Maquette, details photographed in raking light as installed in 2017 exhibition (courtesy of VTM Museum VTM 2184/1-28; photo the authors)

Figure 12.24: Models for portraits (Potgieter 1987, 22-23)

Figure 13.1: D. Murder of Retief. 1949. Marble, $2.3 \times 3.71$ m (courtesy of VTM; photo Russell Scott)

Figure 13.2: A2. W.H. Coetzer. Reproduction of first sketch for Murder of Retief. June 1937 (courtesy of ARCA PV94 $1 / 75 / 5 / 1$; photo the authors)

Figure 13.3: A3. W.H. Coetzer. 'Moord op Retief'. After September 1937. Pencil, $13.5 \times 23$ cm. Revised first sketch (courtesy of Museum Africa, no. 66/2194Q)

Figure 13.4: A4. W.H. Coetzer. Die moord op Retief en sy manskappe. Late 1937-38? Monochrome oil on board, $27.3 \times 46.6 \mathrm{~cm}$ (courtesy of DNMCH, OHG 901; photo the authors)

Figure 13.5: B2. Frikkie Kruger. Murder of Retief. 1942-43. Plaster, $75 \times 120.5 \times 8 \mathrm{~cm}$ (courtesy of VTM Museum VTM 2184/1-28; photo Russell Scott)

Figure 13.6: C2. Murder of Retief. 1943-45. Clay. Full-scale relief (Potgieter 1987, 24; photo Alan Yates, stitched)

Figure 13.7: C1 and C2. Hendrik Ploeger. Left half of wooden armature of Murder of Retief (1943-45) compared with full-scale clay relief, detail of fig. 13.6. (courtesy of Kirchhoff files; photos Alan Yates)

Figure 13.8: C2. Murder of Retief, right half, partly finished state. 1943-45. Clay. Full-scale relief (courtesy of Kirchhoff files; photo Alan Yates)

Figure 13.9: C2. Murder of Retief, right half, finished state. 1943-45. Clay. Full-scale relief (courtesy of Kirchhoff files; photo Alan Yates)

Figure 13.10: Retief's Masonic flask in Murder of Retief, detail of maquette, photographed in raking light as installed in 2017 exhibition (courtesy of VTM Museum VTM 2184/1-28; photo the authors)

Figure 13.11: Retief's Masonic flask in Murder of Retief. Marble, detail of fig. 13.1 (photo Russell Scott) 
Figure 13.12: Masonic flask, GIV-4 type. c. 1815-30. Green glass, $21 \times 11.5 \mathrm{~cm}$. Keene-Marlboro-Street Glass Works, Keene, New Hampshire, USA (courtesy of uMsunduzi Museum Collection; photo the authors)

Figure 13.13a: Topographic Sheets of South Africa (1:50 000). October 2010. Detail, showing uMgungundlovu with kwaMatiwane and Owen's hut at the sendingstasie (mission station) (map 2831AD)

Figure 13.13b: View of uMgungundlovu from the area of Owen's hut. 2015 (photo the authors)

Figure 13.14: Retief as martyr in Murder of Retief. Marble, details of fig. 13.1 (photo Russell Scott)

Figure 13.15: Zulu killing Boers in Murder of Retief. Marble, details of fig. 13.1 (photo Russell Scott)

Figure 13.16: Aerial view of uMgungundlovu in Murder of Retief. Marble, detail of fig. 13.1 (photo Russell Scott)

Figure 13.17: E. Whimper. View of the kraal, or capital, of the kafir chief Dingaan. Umgungundlovu. Etching (Holden 1855, opp. p.81)

Figure 13.18: Sketch of uMgungundlovu following the recollection of Lunguza ka Mpukane, 11.3.1909 Vames Stuart Archive 1, 1976, 309)

Figure 13.19: Masonic flask, GIV-4 type. c. 1815-30. Green glass, $21 \times 11.5 \mathrm{~cm}$. Keene-Marlboro-Street Glass Works, Keene, New Hampshire, USA (courtesy of uMsunduzi Museum Collection; photo the authors)

Figure 13.20: Obverse and reverse drawing of GIV-4 type flask (McKearin and Wilson 1978, 593 GIV-4) next to uMsunduzi flask (photos the authors)

Figure 13.21: 'Veldflesch van Wijlen P. Retief'. Drawing of flask in fig. 13.19 (Hofstede 1876, opp. p.50)

Figure 13.22: W.H. Coetzer. Auction table with (probably Retief's) Masonic flask in 'Uittog uit Kaapland', detail of fig. 1.3. After September 1937 (photo courtesy of Museum Africa, no. 66/2194U)

Figure 14.1: D. Bloukrans. 1950. Marble, $2.3 \times 4.61 \mathrm{~m}$ (courtesy of VTM; photo Russell Scott)

Figure 14.2: Numbered figure schema of major changes in the design process: in red from Coetzer drawing (1937), in green added figures in maquettes, full-scale clay and marble reliefs (1942-50) (the authors)

Figure 14.3: A2. W.H. Coetzer. Reproduction of first sketch for Bloukrans. June 1937 (courtesy of ARCA PV94 1/75/5/1; photo the authors)

Figure 14.4: A3. W.H. Coetzer. 'Blaukrans Moord'. After September 1937. Pencil, $13.5 \times 30.5 \mathrm{~cm}$. Revised first sketch (photo courtesy of Museum Africa, no. 66/2194M)

Figure 14.5: Thomas Baines. Battle of Blauwkrantz. c. 1854. Oil on canvas, $63 \times 77 \mathrm{~cm}$ (Museum Africa; photo https://commons.wikimedia.org/wiki/Category:Thomas_Baines?uselang=de)

Figure 14.6: W.H. Coetzer. Bloukrans-Moord - Middernag - 17 Februarie 1838. Pre-1937. Oil on canvas, $152 \times 84 \mathrm{~cm}$ (location unknown; Nathan 1937, fig. after p.224 'The massacre at Bloukrans')

Figure 14.7: B2a. Laurika Postma. Bloukrans. 1942-43. Plaster, $82 \times 156 \times 10.5 \mathrm{~cm}$. Maquette (courtesy of VTM Museum VTM 2184/1-28; photo Russell Scott)

Figure 14.8: C2. Bloukrans. 1943-45. Clay. Full-scale relief (courtesy of Kirchhoff files; photo Alan Yates)

Figure 14.9: B2b. Laurika Postma. Bloukrans. 1946-47. Plaster, $79 \times 83 \times 9 \mathrm{~cm}$. New maquette for scene on far left, with reversed frenzied Zulu (courtesy of VTM Museum VTM 2184/1-28; photo Russell Scott)

Figure 14.10: B2a. Frenzied Zulu in Bloukrans. Maquette, detail of fig. 14.7 (courtesy of VTM Museum VTM 2184/1-28; photo Russell Scott)

Figure 14.11: Frenzied Zulu torching wagon on far left in Bloukrans. Marble, detail of fig. 14.1 (photo Russell Scott)

Figure 14.12: Zulu killing women and children on far right in Bloukrans. 1943-45. Full-scale clay relief, detail of fig. 14.8 (courtesy of Kirchhoff files; photo Alan Yates)

Figure 14.13: B2c. Laurika Postma. Bloukrans. 1946-47. Plaster, $78 \times 71.8 \times 7 \mathrm{~cm}$. New maquette for scene on far right (courtesy of VTM Museum VTM 2184/1-28; photo Russell Scott)

Figure 14.14: Zulu attack on Boer camps in the Bloukrans area, 16/17.2.1838 (Thom 1947, 207)

Figure 14.15: Topographic Sheets of South Africa (1:50 000). May 2009. Detail, marking Chieveley and the Bloukrans memorial (map 2820 DD)

Figure 14.16: Jesse and William Smith, Bloukrans memorial near Chieveley, view from south (2015). 1897. Brown sandstone and mottled white stone (marble?), estimated height $5.5 \mathrm{~m}$ (photo the authors)

Figure 14.17: Jesse and William Smith, Bloukrans memorial. Detail, front inscription (photo the authors)

Figure 14.18: Jesse and William Smith, Bloukrans memorial. Detail, makers' inscription (photo the authors)

Figure 14.19: Jesse and William Smith, Bloukrans memorial. North-west relief, Zulu massacre women and children (photo the authors)

Figure 14.20: Jesse and William Smith, Bloukrans memorial. South-east relief, Voortrekkers on horseback kill Zulu (photo the authors)

Figure 14.21: Dying young female and elderly woman protecting a baby in Bloukrans. Marble, details of fig. 14.1 (photo Russell Scott)

Figure 14.22: Models for portraits (Potgieter 1987, 26-27)

Figure 14.23: Rand Daily Mail, 15.2.1945 (NARSSA, BNS 146/73/3; photo the authors)

Figure 14.24: Selected records about the Bloukrans controversy, 1945-47 (NARSSA, BNS 146/3/3; table the authors)

Figure 14.25: Centrefold of Monument and frieze panels taken from Yates' photographs, Die Transvaler 13.12.1949 (photo the authors) 
Figure 14.26: C3: Section cut from full-scale plaster relief of Bloukrans with baby being dashed to death. 1943-45 (courtesy of VTM Museum; photo Russell Scott)

Figure 14.27: Peter Paul Rubens. The massacre of the innocents. 1611-12. Oil on oak panel, $142 \times 182 \mathrm{~cm}$ (photo Rubenshuis, Antwerp; https://commons.wikimedia.org/wiki/File:Rubens_-_Massacre_of_the_Innocents_-Art_Gallery_of_Ontario_2.jpg)

Figure 15.1: D. Teresa Viglione. 1949. Marble, $2.3 \times 2.07$ m (courtesy of VTM; photo Russell Scott)

Figure 15.2: B2. Laurika Postma. Teresa Viglione. 1942-43. Plaster, $77 \times 77 \times$ c.8 cm. Maquette (courtesy of VTM Museum VTM 2184/1-28; photo the authors)

Figure 15.3: C2. Teresa Viglione. 1943-45. Clay. Full-scale relief (courtesy of Romanelli files; photo Alan Yates)

Figure 15.4: Models for portraits (Potgieter 1987, 26-27)

Figure 15.5: Lea Spanno, model for Teresa Viglione (Van der Walt 1974, 82)

Figure 15.6: Portrait of the Italian trader on horseback in Teresa Viglione. Marble, detail of fig. 15.1 (photo Russell Scott)

Figure 16.1: D. Dirkie Uys. 1949. Marble, $2.3 \times 2.4$ m (courtesy of VTM; photo Russell Scott)

Figure 16.2: A2. W.H. Coetzer. Reproduction of first sketch for Dirkie Uys. June 1937 (courtesy of ARCA PV94 1/75/5/1; photo the authors)

Figure 16.3: A3. W.H. Coetzer. 'Dirkie Uys'. After September 1937. Pencil, $13.4 \times 15.2 \mathrm{~cm}$. Revised first sketch (photo courtesy of Museum Africa, no. 66/2194H)

Figure 16.4: A4. W.H. Coetzer. Dirkie Uys. Late 1937-38? Monochrome oil on board, $27 \times 27 \mathrm{~cm}$ (courtesy of DNMCH, OHG 902; photo the authors)

Figure 16.5: B2. Laurika Postma. Dirkie Uys. 1942-43. Plaster, $78.5 \times 85 \times 8 \mathrm{~cm}$. Maquette (courtesy of VTM Museum VTM 2184/1-28; photo Russell Scott)

Figure 16.6: C2. Dirkie Uys. 1943-46. Clay. Full-scale relief (Pillman 1984, 48-49, photo Alan Yates)

Figure 16.7: Dirkie Uys. 1943-46. Plaster. Full-scale relief, as installed in the Monument before cleaning (photo courtesy of Unisa Archive; Van Schaik album, MSS 134, 27)

Figure 16.8: Major battle sites, Boer, Zulu, and Swazi, including eThaleni (courtesy of Laband 1995, 106)

Figure 16.9: The glorified hero in Dirkie Uys. Maquette and marble relief, details of figs 16.5 and 16.1 (photos Russell Scott)

Figure 16.10: Models for portraits (Potgieter 1987, 28)

Figure 16.11: Dying Piet Uys in Dirkie Uys. Marble, detail of fig. 16.1 (photo Russell Scott)

Figure 16.12: Apollo kills the Giant Ephialtes, detail of Pergamon Altar, east frieze. c. 200-150 BC. Marble, h. 2.3 m; total length of frieze $113 \mathrm{~m}$ (Pergamonmuseum, Berlin; photo Susanne Muth)

Figure 17.1: D. Marthinus Oosthuizen. 1949. Marble, $2.3 \times 2.4 \mathrm{~m}$ (courtesy of VTM; photo Russell Scott)

Figure 17.2a: Marthinus Oosthuizen? Sketch with Oosthuizen on his horse 'Zwartje' riding through Zulu lines to supply Van Rensburgs with ammunition. Ink and pencil on paper. Undated, h. $33 \times$ w. $20 \mathrm{~cm}$ (photo courtesy of uMsunduzi Museum Collection)

Figure 17.2b: P.J.J. van Rensburg. Modern reconstruction of Marthinus Oosthuizen's site of action. Undated (www.oocities.org/athens/rhodes/1266/RenKopKrt.jpg)

Figure 17.3: Henry Lea. 'De redding door Martinus Oosthuizen van de verdedigers van Rensburg's Kop, Natal 1838' (The rescue by Martinus Oosthuizen of the defenders of Rensburg Koppie, Natal 1838). Pre 1936. Drawing (Muller 1978, 63 fig. 46)

Figure 17.4: B2. Laurika Postma. Marthinus Oosthuizen. 1942-43. Plaster, $77.2 \times 83 \times 10 \mathrm{~cm}$. Maquette (courtesy of VTM Museum VTM 2184/1-28; photo Russell Scott)

Figure 17.5: C2. Marthinus Oosthuizen. 1943-46. Clay. Full-scale relief (Pillman 1984, 52; photo Alan Yates)

Figure 17.6: Simplified copy of Marthinus Oosthuizen(?) sketch, see fig. 17.2a (Muller 1978, 63 fig. 44)

Figure 17.7: Marthinus Oosthuizen on horseback in Marthinus Oosthuizen. Marble, detail of fig. 17.1 (photo Russell Scott)

Figure 17.8: Model for Oosthuizen (Potgieter 1987, 29)

Figure 17.9: Collapsing Zulu in Marthinus Oosthuizen (marble, detail of fig. 17.1; photo Russell Scott) with Zulu model for maquette, fig. 17.4. 1942-43. Harmony Hall garden (Pillman 1984, 53)

Figure 18.1: D. Women spur men on. 1949. Marble, $2.3 \times 2.25$ m (courtesy of VTM; photo Russell Scott)

Figure 18.2: A2. W.H. Coetzer. Reproduction of first sketch for Women spur men on. June 1937 (courtesy of ARCA PV94 1/75/5/1; photo the authors)

Figure 18.3: A3. W.H. Coetzer. 'Vroue eis Vergelding'. After September 1937. Pencil, $13.5 \times 15.3 \mathrm{~cm}$. Revised first sketch (photo courtesy of Museum Africa, no. 66/2194S)

Figure 18.4: B2. Laurika Postma. Women spur men on. 1942-43. Plaster, $77.8 \times 77 \times 8 \mathrm{~cm}$. Maquette (courtesy of VTM Museum VTM 2184/1-28; photo Russell Scott)

Figure 18.5: Models for Women spur men on, lower row for foreground figures, upper row for figures behind them. 1942-43. Pretoria, Harmony Hall garden (photos courtesy of Kirchhoff files) 
Figure 18.6: C2: Women spur men on. 1943-46. Clay. Full-scale relief (courtesy of UP Archives; photo Alan Yates)

Figure 18.7: Models for portraits (Potgieter 1987, 32)

Figure 18.8: Dietloff van Warmelo, model for old man in Women spur men on (Van der Walt 1974, 81)

Figure 18.9: Drakensberg amphitheatre (Mont-Aux-Sources) with Little Tugela River (https://commons.wikimedia. org/wiki/File:Amphitheatre_Drakensberg.jpg; photo Rudolph Botha)

Figure 18.10: Statue of bare-footed Susanna Smit. Pre 1977. Bronze(?), c. life-size. Drakensberg, near Oliviershoek (photo http://www.boerenbrit.com/archives/1669/dsc07865\#main)

Figure 18.11: Inauguration inscription, statue of Susanna Smit. 10 October 1977. Bronze (photo http:// www.boerenbrit.com/archives/1669/dsc07865\#main)

Figure 19.1: D. Arrival. 1949. Marble, $2.3 \times 2.34$ m (courtesy of VTM; photo Russell Scott)

Figure 19.2: A2. W.H. Coetzer. Reproduction of first sketch for Arrival. June 1937 (ARCA PV94 1/75/5/1; photo the authors)

Figure 19.3: B2. Laurika Postma. Arrival. 1942-43. Plaster, $78.2 \times 77 \times 8.6 \mathrm{~cm}$. Maquette (courtesy of VTM Museum VTM 2184/1-28; photo Russell Scott)

Figure 19.4: C2. Arrival. 1943-46. Clay. Full-scale relief (photo courtesy of Kirchhoff files; photo Alan Yates)

Figure 19.5: Models for portraits (Potgieter 1987, 32)

Figure 19.6: Portrait of Willem van Heerden as Boer welcoming Pretorius in Arrival. Marble, detail of fig. 19.1 (photo Russell Scott)

Figure 19.7: Route of the 'Winning Commando', showing the Boer laagers at the Little Tugela River near Sooilaer where Andries Pretorius was appointed head commandant (Liebenberg 1977, 24-25)

Figure 19.8: Andries Pretorius with sabre and pistol in Arrival. Marble, detail of fig. 19.1 (photo Russell Scott)

Figure 19.9: Black servant holding reins of Pretorius' horse in Arrival. Marble, detail of fig. 19.1 (photo Russell Scott)

Figure 20.1: D. The Vow. 1949. Marble, $2.3 \times 2.28$ m (courtesy of VTM; photo Russell Scott)

Figure 20.2: A2. W.H. Coetzer. Reproduction of first sketch for The Vow. June 1937 (courtesy of ARCA PV94 1/75/5/1; photo the authors)

Figure 20.3: A3. W.H. Coetzer. 'Gelofte Danskraal'. After September 1937. Pencil, $13.4 \times 15.4 \mathrm{~cm}$. Revised first sketch (photo courtesy of Museum Africa, no. 66/2194D)

Figure 20.4: B2. Laurika Postma. The Vow. 1942-43. Plaster, $72.5 \times 81.5 \times$ c. $8 \mathrm{~cm}$. Maquette, photographed in raking light as installed in 2017 exhibition (courtesy of VTM Museum VTM 2184/1-28; photo the authors)

Figure 20.5: Coert Steynberg. Relief of the Vow on the Blood River Monument. Granite, detail of fig. 20.13 (photo the authors)

Figure 20.6: C2. The Vow. 1943-46. Clay. Full-scale relief (courtesy of UP Archives; photo Alan Yates)

Figure 20.7: Models for portraits (Potgieter 1987, 32)

Figure 20.8: Two portraits of Sarel Cilliers, in The Vow (marble, detail of fig. 20.1; photo Russell Scott) and photograph, c. 1855 (Gerdener 1925, fig. opp. p.90)

Figure 20.9: Detail of Bible of central trekker in The Vow. Full-scale clay relief (photo Alan Yates; courtesy of UP Archives) and marble (detail of fig. 20.1, photo Russell Scott)

Figure 20.10: The Vow, front pages of Official Guide. Afrikaans and English editions. 1955 (photos the authors)

Figure 20.11: Route of the 'Winning Commando', showing the Pretorius laager at Wasbank, site of the Vow (Liebenberg 1977, 24-25)

Figure 20.12: Coert Steynberg. Early version of the Vow relief in drawing for the Blood River Monument. Before 1938 (DNMCH Archives, Coert Steynberg file; photo the authors)

Figure 20.13: Coert Steynberg. Blood River Monument. Completed 1939/40, inaugurated 1947. Granite, c. $5.8 \times 7.1 \mathrm{~m}$ (Blood River Heritage Site; photo P1010401)

Figure 21.1: D. Blood River. 1950. Marble, $2.3 \times 4.29$ m (courtesy of VTM; photo Russell Scott)

Figure 21.2: A2. W.H. Coetzer. Reproduction of first sketch for Blood River. June 1937 (courtesy of ARCA PV94 $1 / 75 / 5 / 1$; photo the authors)

Figure 21.3: A3. W.H. Coetzer. 'Bloed Rivier’. After September 1937. Pencil, $13.3 \times 23 \mathrm{~cm}$. Revised first sketch (photo courtesy of Museum Africa, no. 66/2194R)

Figure 21.4: W.H. Coetzer. Bloedrivier (Blood River). Stitched by H.J. Combrink, one of fifteen tapestry scenes of the Great Trek for Voortrekker Monument. 1952-60. Wool, $81 \times 183 \mathrm{~cm}$ (courtesy of VTM Museum VTM 0001/14; photo Russell Scott)

Figure 21.5: B2. Peter Kirchhoff. Blood River. 1942-43. Plaster, $79 \times 147 \times$ c. 8 cm. Maquette, photographed in raking light as installed in 2017 exhibition (courtesy of VTM Museum VTM 2184/1-28; photo the authors)

Figure 21.6: C2. Blood River. 1943-46. Clay. Full-scale relief (courtesy of Kirchhoff files; photo Alan Yates)

Figure 21.7: Kneeling Zulu in Blood River whose little toe crosses into The Vow. Marble, detail of fig. 21.1 (photo Russell Scott) 
Figure 21.8: Route of the 'Winning Commando', showing the site of the Battle of Blood River (Liebenberg 1977, 24-25)

Figure 21.9: Battle of Blood River. John Laband's reconstruction of Boer laager and Zulu attack (Laband 1995, 90)

Figure 21.10: Collapsing Zulu in front of Pretorius in Blood River. Marble, detail of fig. 21.1 (photo Russell Scott)

Figure 21.11: Coert Steynberg. Blood River Monument. Completed 1939/40, inaugurated 1947. Granite, c. $5.8 \times 7.1 \mathrm{~m}$ (Blood River Heritage Site; photo the authors)

Figure 21.12: Coert Steynberg. Relief with Battle of Blood River, Blood River Monument. Granite, detail of fig. 21.11 (photo the authors)

Figure 21.13: Roman sarcophagus Ludovisi, Romans defeat barbarians. c. AD 250. Marble, $153 \times 273 \mathrm{~cm}$ (Rome, Palazzo Altemps 8574; photo https://commons.wikimedia.org/wiki/Category:Grande_Ludovisi_ sarcophagus?uselang=de\#/media/File:Grande_Ludovisi_sarcophagus.jpg)

Figure 21.14: Aerial view of commemorative laager at Blood River, with the Ncome-Blood River Heritage Site in the background. 1971 (photo courtesy of Freddy Reck, www.Reckfilm.de)

Figure 21.15: One of sixty-four full-size Voortrekker wagons replicated for commemorative laager at Blood River. 1971. Bronzed cast iron (photo the authors)

Figure 21.16: Aerial view of new museum complex at the Ncome-Blood River Heritage Site, inaugurated 1998 (photo courtesy of uMsunduzi and Ncome Museums)

Figure 22.1: D. Church of the Vow. 1943-46. Marble, $2.3 \times 2.19$ m (courtesy of VTM; photo Russell Scott)

Figure 22.2: A2. W.H. Coetzer. Reproduction of first sketch for Church of the Vow. June 1937 (courtesy of ARCA PV94 $1 / 75 / 5 / 1$; photo the authors)

Figure 22.3: A3. W.H. Coetzer. 'Bou van Gelofte Kerkie'. After September 1937. Pencil, $13.4 \times 15.4 \mathrm{~cm}$. Revised first sketch (photo courtesy of Museum Africa, no. 66/2194G)

Figure 22.4: B2. Peter Kirchhoff. Church of the Vow. 1942-43. Plaster, $77.2 \times 76.2 \times 8 \mathrm{~cm}$. Maquette (courtesy of VTM Museum VTM 2184/1-28; photo Russell Scott)

Figure 22.5: C2. Church of the Vow. 1943-46. Clay. Full-scale relief (courtesy of Kirchhoff files; photo Alan Yates)

Figure 22.6: Models for portraits (Potgieter 1987, 34)

Figure 22.7: Peter Kirchhoff models portrait of Gerard Moerdyk at Harmony Hall, Pretoria. c. 1944. Clay, c. life-size (photo courtesy of Kirchhoff files)

Figure 22.8: Peter Kirchhoff's portrait of Gerard Moerdyk. c. 1944. Clay, c. life-size (photo courtesy of Kirchhoff files)

Figure 22.9: Portrait of Gerard Moerdyk in Church of the Vow. Marble, detail of fig. 22.1 (photo Russell Scott)

Figure 22.10a: A.N. Sherson. Plan of Bushman's Rand/Pieter Maretz Burg. March 1839. Ink (courtesy of NA Kew, Colonial Office, MPG 1/144; photo the authors)

Figures 22.10b-c: Details of fig. 22.10a, plan of Bushman's Rand/Pieter Maretz Burg

Figure 22.11: HM Commissioner H. Cloete. Central Pietermaritzburg, detail of Register of erven claimed, with names of claimants at Durban, Congella, Pietermaritzburg and Weenen, with erf 34 marked with black frame. 1843 (courtesy of Pietermaritzburg Archives Repository; photo Elrica Henning)

Figure 22.12: C. Piers and L. Cloete. Pietermaritzburg land register map, with erf 34 marked with black frame. November 1845 (Laband and Haswell 1988, 22)

Figure 22.13: Central area of Pietermaritzburg land register map, detail of fig. 22.12 (Laband and Haswell 1988, 22)

Figure 22.14: Marianne Churchill. Church Street and east end of Pietermaritzburg market square with parsonagechurch. 1854. Sepia drawing (Durban, Local History Museum; Muller 1978, 83 fig. 66)

Figure 22.15: East side of Pietermaritzburg market square with former parsonage-church (left) and front of 1861 Dutch Reformed Church (right) in background. 1880s (photo courtesy of uMsunduzi Museum Collection, Church of the Vow file)

Figure 22.16: Pietermaritzburg Council Chamber and Court with Dutch holbol-type gable. 1840 (Buchanan 1934, fig. opp. p.24)

Figure 22.17: G.H. Gordon. 'View of Dutch Church and school house' Pietermaritzburg, Dutch Reformed Church (left) and former parsonage-church (right) as viewed from Boshoff Street. 1861-73. Watercolour (photo courtesy of uMsunduzi Museum Collection, Church of the Vow file)

Figure 22.18: Alex Mair, surveyor. Central area of Pietermaritzburg land register map, with erf 34 marked in red. 1869 (Durban, Local History Museum; Laband and Haswell 1988, 34 fig. 4)

Figure 22.19: North-west corner of enlarged former parsonage-church when used as a Dining \& Refreshment Room. c. 1891-97 (photo courtesy of uMsunduzi Museum Collection, Church of the Vow file)

Figure 22.20: North-east corner of former parsonage-church during restoration works for new Voortrekker Museum. 1911 (The Natal Witness 22.8.1911, p.1; photo courtesy of uMsunduzi Museum Collection, Church of the Vow file)

Figure 22.21: North-west corner of restored former parsonage-church as new Voortrekker Museum. 17.11.1911 (photo courtesy of uMsunduzi Museum Collection, Church of the Vow File)

Figure 22.22: North-west corner of restored former parsonage-church as Voortrekker Museum with added porch. 1917 (photo courtesy of uMsunduzi Museum Collection, Church of the Vow file) 
Figure 22.23: John Daniel Kestell. Undated drawing of Dutch holbol-type gable attributed to Pietermaritzburg parsonage-church (Van Rooyen 1938, 158)

Figure 22.24: Geloftekerkie. Stamp issued for Voortrekker Memorial Fund. 1933-36 (Guest 2012, 49)

Figure 22.25: uMsunduzi Museum and Voortrekker Complex, Pietermaritzburg (Henning 2014, 185 fig. 164)

Figure 22.26: Harry Atkins. Voortrekker frieze of E.G. Jansen extension. Inaugurated 6 April 1960. Stone, h. $1.10 \times$ w. $4.40 \mathrm{~m}$ (uMsunduzi Museum and Voortrekker Complex; photo courtesy of Louis Eksteen)

Figure 22.27: P.R. le Roux. Entrance façade of Pietermaritzburg Memorial Church. Inaugurated 6 April 1962 (uMsunduzi Museum and Voortrekker Complex; photo the authors)

Figure 22.28: Coert Steynberg. Statue of Piet Retief. Inaugurated 5 April 1961. Bronze, $2.7 \mathrm{~m}$ (uMsunduzi Museum and Voortrekker Complex; photo the authors)

Figure 22.29: Jo Roos. Statue of Gerrit Maritz. Inaugurated 16 December 1970. Bronze, $2.7 \mathrm{~m}$ (uMsunduzi Museum and Voortrekker Complex; photo the authors)

Figure 22.30: Coert Steynberg. 'The fulfilment of the Vow 1839-1840'. Back relief of Blood River Monument, depicting restored former Pietermaritzburg parsonage-church as Voortrekker Museum with added porch. Inaugurated on 16 December 1947. Granite, see fig. 20.13 (photo the authors)

Figure 22.31: Workman refining gable's moulded volute in Church of the Vow. Marble, detail of fig. 22.1 (photo Russell Scott)

Figure 23.1: D. Peter Kirchhoff. Saailaer. 1949. Marble, $2.3 \times 4.01 \mathrm{~m}$ (courtesy of VTM; photo Russell Scott)

Figure 23.2: B2. Peter Kirchhoff. Saailaer. 1942-43. Plaster, $77 \times 142.7 \times$ c. 8 cm. Maquette (courtesy of VTM Museum VTM 2184/1-28; photo Russell Scott)

Figure 23.3: C2. Saailaer. 1943-46. Clay. Full-scale relief (courtesy of Kirchhoff files; photo Alan Yates)

Figure 23.4: 'Harmonie S., Vera, 1942, Voortrekker Nooi' (Harmony Hall, Vera [Kirchhoff], 1942, Voortrekker maiden), model for Saailaer, with an additional unknown model for the sowing woman bottom left (photos courtesy of Kirchhoff files)

Figure 23.5: Model for portraits (Potgieter 1987, 35)

Figure 23.6: Armed kneeling woman with changed hairstyle in Saailaer. Full-scale clay relief and marble, details of figs 23.1 and 23.3 (photos Alan Yates; Russell Scott)

Figure 23.7: Saailaer mounted in Hall of Heroes. c. 1949. Marble (photo courtesy of Unisa Archive, Van Schaik album, MSS 134, 27)

Figure 23.8: North-west Natal, showing the sites of Sooilaer and Saailaer near Estcourt (Thom 1947, 247)

Figure 23.9: Landscape and attacking Zulu crossing Bushman's River in a chain in Saailaer. Marble, detail of fig. 23.1. (photo Russell Scott)

Figure 23.10: Natal, Bushman's River? Undated and without location (photo courtesy of HF Archives F 02-0314F)

Figure 23.11: Hall of Heroes, west frieze. On the far left, Women spur men on; on the far right, Saailaer (courtesy of VTM; photo Russell Scott)

Figure 24.1: D. Mpande. 1949. Marble, $2.3 \times 2.4 \mathrm{~m}$ (courtesy of VTM; photo Russell Scott)

Figure 24.2: A2. W.H. Coetzer. Reproduction of first sketch for Mpande. June 1937 (courtesy of ARCA PV94 1/75/5/1; photo the authors)

Figure 24.3: A3. W.H. Coetzer. 'MPanda'. After September 1937. Pencil, $13.4 \times 15.4 \mathrm{~cm}$. Revised first sketch (photo courtesy of Museum Africa, no. 66/2194T)

Figure 24.4: B2. Frikkie Kruger. Mpande. 1942-43. Plaster, $75.5 \times 86 \times 8 \mathrm{~cm}$. Maquette (courtesy of VTM Museum VTM 2184-28/1-28; photo Russell Scott)

Figure 24.5: C2. Mpande. 1943-46. Clay. Full-scale relief (courtesy of UP Archives; photo Alan Yates)

Figure 24.6: Models for portraits (Potgieter 1987, 36)

Figure 24.7: Map showing relevant sites and territory seized by Boers from Mpande in 1840 (courtesy of Laband 1995, 106)

Figure 24.8: Pandaklippe (Mpande's stones), said to commemorate Mpande’s crowning as Zulu king and peace treaty between Boers and Zulu. 10.2.1840 (photo https://resolver.kb.nl/resolve?urn=urn: gvn:ZAH01:100000107)

Figure 24.9: Mpande and Pretorius in Mpande. Marble, detail of fig. 24.1 (photo Russell Scott)

Figure 25.1: D. Death of Dingane. 1949. Marble, $2.3 \times 2.4 \mathrm{~m}$ (courtesy of VTM; photo Russell Scott)

Figure 25.2: B2. Laurika Postma. Death of Dingane. 1942-43. Plaster, $77.5 \times 84.7 \times 9 \mathrm{~cm}$. Maquette (courtesy of VTM Museum VTM 2184/1-28; photo Russell Scott)

Figure 25.3: C2. Death of Dingane. 1943-46. Clay. Full-scale relief (Pillman 1984, 53; photo Alan Yates)

Figure 25.4: Map showing the Maqongqo and Lubuye (not Lubuya as on map) battle sites, Phongolo River and Lubombo Mountains in upper section (courtesy of Laband 1995, 106)

Figure 25.5: Head of dying Dingane in Death of Dingane. Marble, detail of fig. 25.1 (photo Russell Scott)

Figure 25.6: Dying Dingane in Death of Dingane. Marble, detail of fig. 25.1 (photo Russell Scott)

Figure 25.7: Dingane's wives in Death of Dingane. Marble, detail of fig. 25.1 (photo Russell Scott) 
Figure 25.8: Jan Juta. 1700. ... native life ... as developed under Christian and governmental teaching. 1934. Oil on canvas, $150 \times 58 \mathrm{~cm}$ (South Africa House, London; Freschi 2006, 217 fig. 27)

Figure 26.1: D. Return. 1949. Marble, $2.3 \times 4.29$ m (courtesy of VTM; photo Russell Scott)

Figure 26.2: A2. W.H. Coetzer. Reproduction of first sketch for Return. June 1937 (courtesy of ARCA PV94 1/75/5/1; photo the authors)

Figure 26.3: A3. W.H. Coetzer. 'Terugtog oor Drakensberg'. After September 1937. Pencil, $13.3 \times 30.4$ cm. Revised first sketch (photo courtesy of Museum Africa, no. 66/21940)

Figure 26.4: A4. W.H. Coetzer. Terug oor Drakensberg. c. 1937-38. Monochrome oil on board, $27.5 \times 62 \mathrm{~cm}$ (courtesy of DNMCH, OHG 900; photo the authors)

Figure 26.5: B1. Frikkie Kruger. Return. Clay. Maquette on easel (courtesy of Kirchhoff files; photo the authors)

Figure 26.6: B2. Frikkie Kruger. Return. 1942-43. Plaster, $78 \times 152.7 \times 8 \mathrm{~cm}$. Maquette (courtesy of VTM Museum VTM 2184/1-28; photo Russell Scott)

Figure 26.7: C2. Return. 1943-45. Clay. Full-scale relief (courtesy of Kirchhoff files; photo Alan Yates)

Figure 26.8: Chicken coop and sacks on wagon in Return. Marble, detail of fig. 26.1 (photo Russell Scott)

Figure 26.9: Models for portraits (Potgieter 1987, 39)

Figure 26.10: Aloes growing in stony ground in Return. Full-size clay and marble, details of figs 26.7 and 26.1 (photos Alan Yates; Russell Scott)

Figure 26.11: 'South Africa 1834-48' (Walker 1934, foldout after p.377)

Figure 26.12: South Africa, 1847-54. Red-coloured districts annexed by Governor Sir Harry Smith, those lightly coloured becoming part of Cape Colony (Moore Smith 1902, opp. p.236)

Figure 27.1: D. Convention. 1949. Marble, $2.3 \times 2.82$ m (courtesy of VTM; photo Russell Scott)

Figure 27.2: A2. W.H. Coetzer. Reproduction of first sketch for Convention. June 1937 (courtesy of ARCA PV94 $1 / 75 / 5 / 1$; photo the authors)

Figure 27.3: A3. W.H. Coetzer. 'Konvensies van Zand Rivier binne in 'n Tent'. After September 1937. Pencil, $13.4 \times$ $15.3 \mathrm{~cm}$. Revised first sketch (photo courtesy of Museum Africa, no. 66/2194L)

Figure 27.4: B2. Peter Kirchhoff. Convention. 1942-43. Plaster, $79 \times 87 \times 9.5 \mathrm{~cm}$. Maquette (courtesy of VTM Museum VTM 2184/1-28; photo Russell Scott)

Figure 27.5: C2. Convention. 1943-45. Full-scale relief. Clay (courtesy of Kirchhoff files; photo Alan Yates) Figure 27.6: Zuid-Afrikaansche Republiek (ZAR) in 1881 (Cachet 1882, foldout map opp. p.330, photo Roy Hessing) Figure 27.7: Map showing the site of the Sand River Convention in the Orange Free State (https://mapcarta. com/14261228/Map)

Figure 27.8: W.H. Coetzer. 'Reconciliation between Potgieter and Pretorius' (Nathan 1937, opp. p.340)

Figure 27.9: Models for portraits (Potgieter 1987, 39)

Figure 27.10: Portraits of Pretorius, Hogge and Owen in Convention. Marble, details of fig. 27.1 (photos Russell Scott) Figure 27.11: English officers in Convention. Marble, detail of fig. 27.1 (photo Russell Scott)

Figure 27.12: C.C.P. Lawson. Officer, Cape Mounted Rifles, 1847. Watercolour (Tylden 1938, fig. opp. p.228)

Figure 27.13: Phil Minnaar. Bust of Major Henry Douglas Warden (1800-56), in dress jacket with frogging of Cape Mounted Rifles. 2002. Bronze, h. 64 cm (courtesy of Queen's Fort Military Museum, Bloemfontein; photos, Ernene Verster)

Figure 27.14: Presentation of Major Warden's bust in Bloemfontein, 31.10.2002 (courtesy of Ingrid Howard)

Figure 27.15: Memorial at the site of the signing of the Sand River Convention. 1958 (photo the authors)

Ground plan at the end with layout of the scenes in the Hall of Heroes (drawing Tobias Bitterer)

Three-page foldout at the end with the frieze of the Voortrekker Monument (courtesy of VTM; photos Russell Scott) 
